\title{
PROPERDIN AND THE DEFENCE OF BURNS AGAINST INFECTION
}

\author{
By E. J. L. LOWBURY, D.M., B.M. and C. R. RICKETTS, Ph.D., F.R.I.C. \\ WITH THE TECHNICAL ASSISTANCE OF \\ M. HALL, A.I.M.L.T., L. HURST, F.I.M.L.T. \\ AND H. A. LILLY, A.I.M.L.T. \\ The Medical Research Council Industrial Injuries and Burns Unit, \\ Birmingham Accident Hospital
}

(With 4 Figures in the Text)

\begin{abstract}
Properdin is a serum protein fraction which shows bactericidal activity in the presence of complement and magnesium ions (Pillemer, Blum, Lepow, Ross, Todd \& Wardlaw, 1954; Pillemer, 1955; Pillemer, Schoenberg, Blum \& Wurz, 1955; Pillemer \& Ross, 1955; Pillemer, Blum, Lepow, Wurz \& Todd, 1956). It is not regarded as an antibody and it can be adsorbed from serum on to zymosan, an insoluble polysaccharide residue of yeast cells. Subsequent elution yields a concentrated solution of properdin. When the adsorption of properdin is carried out at $37^{\circ} \mathrm{C}$., complement is inactivated through the removal of its third component $\left(\mathrm{C}_{3}^{\prime}\right)$. After adsorption at $17^{\circ} \mathrm{C}$., however, the supernatant solution contains active complement, but is almost free from properdin and can therefore be used as a reagent for the assay of properdin.

In view of the importance of natural defences and the limitations of chemotherapy in the control of wound infection, it seemed to us that properdin might have an important function in this field. We report here some preliminary studies which refer in particular to the possible role of properdin in the defence of burns against infection.
\end{abstract}

\section{MATERIALS AND METHODS \\ Zymosan}

Following the method of Pillemer \& Ecker (1941) preparations of zymosan were made by prolonged incubation of yeast with trypsin and repeated extraction of the residue with water and alcohol. One of these, $\mathrm{Z} 2$ (from baker's yeast), was effective in properdin assay at $0.5-2.0 \mathrm{mg}$. per $\mathrm{ml}$. of serum as described by Pillemer et al. (1954). Another preparation, Z 1 (from brewer's yeast), showed anticomplementary activity at $17^{\circ} \mathrm{C}$. This preparation was found to contain $2 \%$ phosphorus and to be slightly metachromatic on staining with toluidine blue. Further extraction with hot water reduced the phosphorus content to $0.05 \%$ and abolished the anticomplementary activity, enabling the zymosan to be used in assays. It is probable that polymeric phosphates, known to occur in yeast and to be metachromatic and anticomplementary, were removed by the extraction. 
A further preparation Z4, by the method of Pillemer et al. (1956), resembled Z 1 in having an anticomplementary action.

The insoluble carbohydrate of yeast cells is a mixture of the polysaccharides glycogen (glucose units joined mainly by $\alpha 1: 4$ links), mannan (mannose units joined by $\alpha$ 1:6 links) and glucan (glucose units joined by $\beta$ 1:3 links) (Trevelyan \& Harrison, 1952). Acidic hydrolysis of the zymosan preparations $\mathrm{Z}_{1}$ and $\mathrm{Z} 2$, followed by electrophoresis in borate buffer (Foster, 1953), showed the presence of glucose and mannose derived from these polysaccharides. Glycogen was not detected in the zymosans by staining with iodine. A considerable amount of material insoluble in hot $2 \mathrm{~N}$ sulphuric acid was present in both preparations. Thus two samples corresponding, so far as can be ascertained, in biological and in chemical properties with the published descriptions of zymosan were available for the assay and preparation of properdin.

\section{Properdin}

A uniform suspension of zymosan was prepared by shaking $164 \mathrm{mg}$. of $\mathrm{Z} 2$ in $10 \mathrm{ml}$. saline with glass beads. The suspension was added to human serum (82 ml.) and stirred slowly at $17^{\circ} \mathrm{C}$. for $2 \mathrm{hr}$. After centrifuging (2700 r.p.m., $6^{\circ} \mathrm{C} ., 5 \mathrm{~min}$.) the supernatant solution was removed and the precipitate washed three times with $2 \mathrm{ml}$. saline at $6^{\circ} \mathrm{C}$. The precipitate was suspended in buffer solution of $\mathrm{pH} 7.5$ and ionic strength 0.6 and stirred slowly at $37^{\circ} \mathrm{C}$. for $30 \mathrm{~min}$. to elute the properdin. After centrifuging, the supernatant solution was dialysed against distilled water. The precipitate was dissolved in saline $(1 \mathrm{ml}$.), divided into $0.1 \mathrm{ml}$. portions and stored at $-20^{\circ} \mathrm{C}$. A micro-Kjeldahl analysis showed a total of $4.05 \mathrm{mg}$. protein which contained 20 units (see below, under Assay of properdin) of properdin per ml. by assay. Electrophoresis ( $\mathrm{pH} 8 \cdot 6$ ) on a paper strip followed by staining with bromo phenol blue showed the presence of slowly migrating protein in the $\gamma$ globulin region, a heavy deposit at the origin, $\beta$ globulin and a trace of $\alpha_{2}$ globulin.

Similarly, bovine serum (480 ml.) yielded $18.5 \mathrm{mg}$. protein containing 40 units of properdin activity per $\mathrm{ml}$. and showing a similar electrophoresis pattern (Fig. 1).

\section{Reagents for properdin assay}

A serum deficient in properdin but having the four components of complement and $\mathrm{Mg}^{2+}$ ions at normal concentrations is essential for demonstration of properdin activity. For the zymosan assay a moderate depletion suffices (RP), but for demonstration of bactericidal power a more thorough removal of properdin is necessary $\left(\mathrm{RP}_{b}\right)$. Serum deficient in the third component but containing the other three components of complement (R3) is required to check that RP contains this component. Reagents were divided into convenient portions and stored at $-79^{\circ} \mathrm{C}$.

(i) $R P$. Serum (100-120 ml.) from a selected donor was stirred slowly at $17^{\circ} \mathrm{C}$. for $75 \mathrm{~min}$. with a suspension of zymosan $(1 \mathrm{ml} . \mathrm{Z} 2$ per $\mathrm{ml}$. serum) prepared by shaking the zymosan in saline $(10 \mathrm{ml}$.) with glass beads. After centrifuging at $6^{\circ} \mathrm{C}$. the clear supernatant was separated. 
(ii) $R P_{b}$. Serum $\left(50 \mathrm{ml}\right.$.) was treated with zymosan $\left(1 \mathrm{ml} . \mathrm{Z} 2\right.$ per ml.) at $17^{\circ} \mathrm{C}$. for $75 \mathrm{~min}$. and again with fresh zymosan at $37^{\circ} \mathrm{C}$. for $30 \mathrm{~min}$.

(iii) $R 3$. Serum $\left(50 \mathrm{ml}\right.$.) was treated with zymosan $(1 \mathrm{ml} . \mathrm{Z} 2$ per ml. $)$ at $37^{\circ} \mathrm{C}$. for $1 \mathrm{hr}$.

\section{Buffer solutions $\mathrm{pH} \mathbf{7 \cdot 5}$}

(i) Ionic strength $0 \cdot 15$. Sodium acetate $3 \mathrm{H}_{2} \mathrm{O}(9 \cdot 714 \mathrm{~g}$.), sodium diethyl barbiturate (14.714 g.) and sodium chloride (17.0 g.) were dissolved in $2460 \mathrm{ml}$. water and the $\mathrm{pH}$ was adjusted with normal hydrochloric acid $(43 \mathrm{ml}$.).

(ii) Ionic strength $0 \cdot 60$. The buffer of ionic strength $0 \cdot 15(3.5$ parts by volume) was mixed with $2 \mathrm{M}$ sodium chloride ( 9 parts by volume).

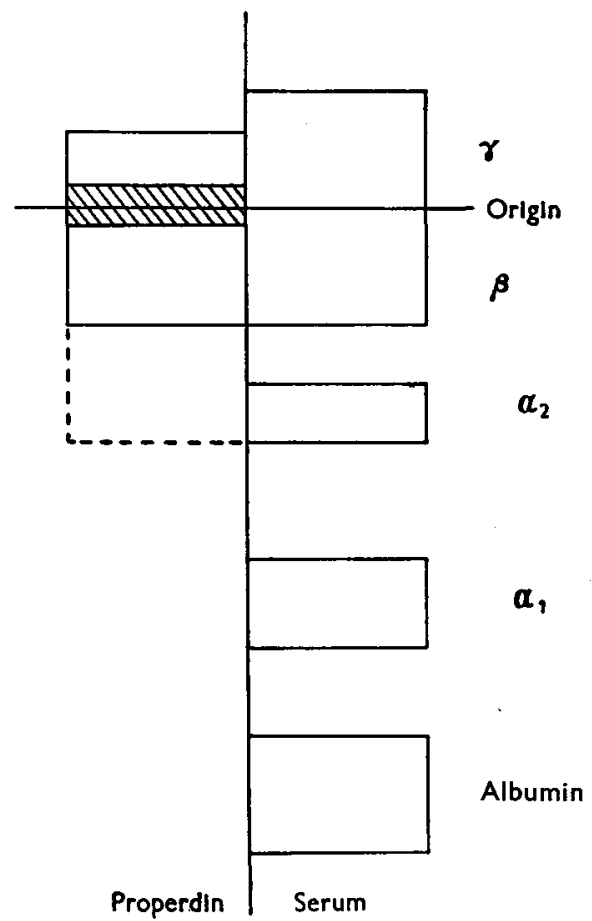

Fig. 1. Diagram illustrating electrophoretic separation of the proteins present in a concentrated solution of bovine properdin. Bovine serum proteins separated under the same conditions are shown alongside.

\section{Standardization of the reagents}

In most particulars we followed the recommendations of Pillemer et al. (1956), whose paper should be consulted for a detailed account of the zymosan assay of properdin.

$R P$. Complement $\left(\mathrm{C}^{\prime}\right)$ and the third component of complement $\left(\mathrm{C}_{3}^{\prime}\right)$ were titrated with sensitized sheep erythrocytes, the former to $100 \%$ and the latter to $50 \%$ end-points. RP was accepted for use if its $\mathrm{C}^{\prime}$ titre was at least $75 \%$ of that in the original serum, and if it lost no more than $25 \%$ of its $\mathrm{C}_{3}^{\prime}$ when treated with further zymosan at $37^{\circ} \mathrm{C}$. for $1 \mathrm{hr}$. Our RP contained 250 units $\mathrm{C}_{3}^{\prime}$ per ml., and was diluted 1 in 2 with veronal buffer (Pillemer et al. 1956) for use. 
$R 3$. This was accepted if $(a)$ it failed to cause haemolysis of sensitized sheep red cells at twice and four times the concentration at which the original serum caused $100 \%$ haemolysis (2- and 4-unit levels); $(b)$ it was free from anticomplementary activity; and $(c)$ it caused $70-100 \%$ haemolysis at the 2-unit level on 'recombination' with the original serum diluted to $\frac{1}{4}$-unit level.

Only five out of sixteen sera tested for R 3 production were found suitable. Of these, four were also suitable for the preparation of RP.

Zymosan. The concentrations giving the most satisfactory result were selected for use in the assay and preparation of properdin. These were determined by incubating $1 \mathrm{ml}$. of fresh serum with $0.5,1 \cdot 0,2 \cdot 0$ and $4.0 \mathrm{mg}$. of zymosan, and preparing $\mathrm{RP}$ and $\mathrm{R3}$ as described above.

\section{Assay of properdin}

RP (0.25 ml.), zymosan suspension $(0.25 \mathrm{ml}$., usually at $1 \mathrm{mg} . / \mathrm{ml}$.) and the solution for assay $(0.25 \mathrm{ml}$. in a range of doubling dilutions) were mixed, incubated in a water-bath at $37^{\circ} \mathrm{C}$. for $1 \mathrm{hr}$., and centrifuged. In the presence of properdin, $\mathrm{C}_{3}^{\prime}$ is removed from $\mathrm{RP}$ by zymosan. A titre of properdin was obtained by testing the clear supernatants for $C_{3}^{\prime}$ (i.e. testing for complement in the presence of R3) and noting the highest dilution of the material under test which caused the removal of all complement activity from the RP-zymosan mixture. A standard properdin solution, or a serum of known properdin content stored at $-79^{\circ} \mathrm{C}$. was used as a control with every batch of tests. Compared with frozen solution, properdin retained only one-quarter of its activity when freeze-dried alone, but about threequarters when freeze-dried from $5 \%$ lactose.

We have followed Pillemer in defining the unit of properdin as that quantity which completely inactivates the $\mathrm{C}_{3}^{\prime}$ in $1 \mathrm{ml}$. of $\mathrm{RP}$ at the dilution of the reagent used for the test.

\section{Demonstration of bactericidal action}

Strains of Proteus (6), Pseudomonas pyocyanea (4), Bacterium coli (5) and Klebsiella (4) isolated from burns were tested by the method of Miles and Misra (see Miles, Misra \& Irwin 1938) for sensitivity to the bactericidal action of a serum containing properdin. Control tests were made with serum heated for $60 \mathrm{~min}$. at $56^{\circ} \mathrm{C}$.

Three strains (one each of $P$ s. pyocyanea, Proteus and Klebsiella) found resistant by the first test were also tested as follows. Tubes containing $0.48 \mathrm{ml}$. amounts of serum were inoculated with $0.02 \mathrm{ml}$. of a thrice-washed suspension containing approximately $25 \times 10^{4}$ organisms per $\mathrm{ml}$. (by Brown's opacity standard); $0 \cdot 1 \mathrm{ml}$. amounts were spread on nutrient agar plates initially and after intervals of 5,15 30,60 and $120 \mathrm{~min}$. of incubation at $37^{\circ} \mathrm{C}$, and surface viable counts were made after incubating the plates at $37^{\circ} \mathrm{C}$. for $18 \mathrm{hr} .^{*}$ This test showed small degrees of sensitivity of organisms to the bactericidal action of serum which were not detected by the method of Miles and Misra. The latter, however, gave a better index of major differences in sensitivity.

* This method is based upon one described to us by Dr A. C. Wardlaw (see Wardlaw \& Pillemer, 1956). 
A properdin sensitive organism kindly supplied by Dr A. C. Wardlaw (Shigella dysenteriae 377) was used as a control in sensitivity tests on bacteria from burns, and as an indicator organism in studies on the bactericidal activity of serum from burned patients. With this organism we also made a comparison of the bactericidal activity of fresh serum, $\mathrm{RP}_{b}$ and $\mathrm{RP}_{b}+$ added properdin ( 2 units per ml.).

\section{RESULTS}

Properdin level in serum of burned patients and normal subjects

Table 1 shows the results of properdin assay in the sera of twelve normal subjects and eighteen burned patients. Three of the former and nine of the latter were bled and tested for properdin on more than one occasion, and the table shows one result (the lowest titre) obtained for each individual. Blister fluids from the burns

Table 1. Properdin in serum and blister fluid

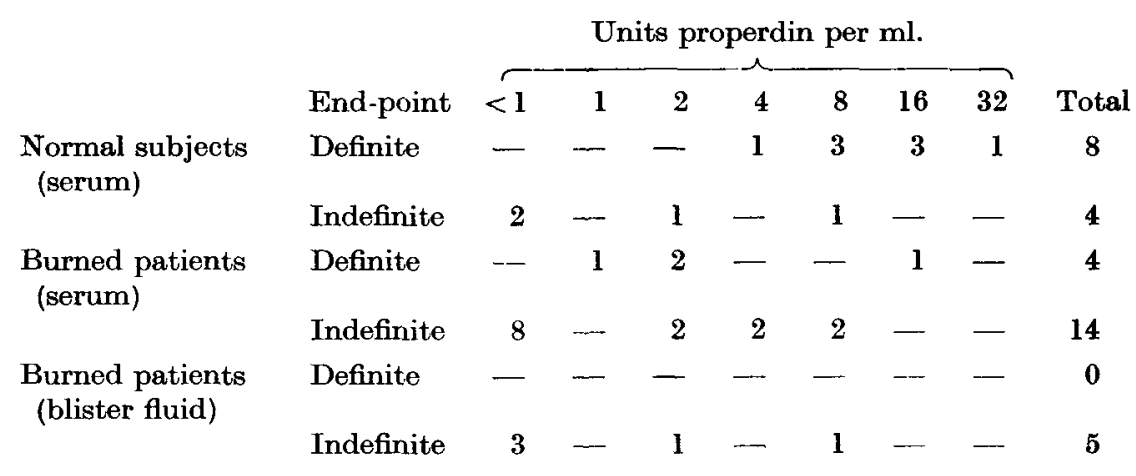

of five patients were also tested. It is seen that $8 / 12$ normal subjects showed measurable properdin ranging from 4 to 32 units per ml.; by contrast, only 4/18 sera from burned patients showed measurable properdin (between 1 and 16 units per ml.); properdin could not be detected in eight. Measurable properdin could not be found in any of the five samples of blister fluid, and in three of them properdin was not detectable. Two patients tested during the 'shock phase', when there were few bacteria on the burn, and again later when there were numerous bacteria, showed a normal titre in the first and no detectable properdin in the second sample. In contrast with the marked variability of properdin in the serum of burned patients, repeated sampling of two normal subjects showed very little variation.

\section{Interpretation of tests}

Tests on a number of human sera and on concentrated solutions of properdin gave results similar in effect to those which have been described by Pillemer. The test was particularly suitable for the assay of preparations of properdin. Serum and blister fluid, on the other hand, often gave results which were difficult to interpret. These took the form of a zone effect, in which haemolysis of sheep cells was caused by the supernatants from the tubes containing the highest and the 
lowest concentrations of the material under test, tubes in the middle of the range showing no haemolysis. The highest dilution showing complete absence of haemolytic effect was accepted as an end-point of the assay. In many tests, however, there was complete haemolysis at the ends and partial haemolysis in the middle of the range, and a quantitative estimate of the properdin level of these sera could not be made. The partial inhibition of haemolytic power was accepted as qualitative evidence of the presence of properdin, and for purposes of tabulation the tube or tubes showing maximum inhibition were described as indicating an 'indefinite' end-point. The haemolysis at the higher concentrations of serum in the test were at first thought to be due to an excess of complement carried over in the test; but we found that unsensitized sheep cells were also haemolysed by these supernatants -in fact, the assay of properdin could be carried out using unsensitized instead of sensitized sheep cells. It seemed, therefore, that a haemolytic antibody in human serum and RP was responsible for this effect. In the light of these findings it is difficult to interpret tests in which all the tubes show complete haemolysis, but from an analysis of the results we regard them as providing qualitative evidence of a low properdin level.

\section{Bactericidal action}

\section{Effect of properdin-containing serum on burn flora}

As a preliminary step, six strains of Proteus, five of Bact. coli, four of Ps. pyocyanea and four of Klebsiella isolated from burns were screened for sensitivity to serum containing properdin. Three out of four of the Bact. coli strains and one Klebsiella were highly sensitive, but all the other strains were resistant (or slightly sensitive) by the method of Miles and Misra (Table 2). By a more searching test,

Table 2. Bactericidal effect of serum on burn flora

(Method of Miles and Misra.)

Percentage survival after $2 \mathrm{hr}$. exposure to serum

$\begin{array}{lcccccc}\quad \text { Organism } & \text { Strain 1 } & \text { Strain 2 } & \text { Strain 3 } & \text { Strain 4 } & \text { Strain 5 } & \text { Strain 6 } \\ \text { Proteus } & 36 & 120 & 72 & 60 & 280 & 80 \\ \text { Ps. pyocyanea } & 38 & 17 & 55 & 38 & - & - \\ \text { Klebsiella } & 364 & 0.07 & 119 & 70 & - & - \\ \text { Bact. coli } & 0.16 & 0.29 & 0.61 & 1.05 & 20 & - \\ \text { Control } & 0.07 & - & - & - & - & - \\ \text { (Shigella 377) } & & & & & & \end{array}$

one out of three strains shown to be resistant by the first method showed a transient fall (to approximately $17 \%$ of the initial count); compared with the sensitive Shigella and Bact. coli strains, however, this organism must be considered relatively resistant (Fig. 2).

\section{Bactericidal effect of properdin}

An example of the bactericidal action of properdin on the control sensitive strain was shown in parallel tests with serum, $\mathrm{RP}_{b}$ derived from the same serum, and $\mathrm{RP}_{b}$ to which properdin was added to a concentration of 2 units per $\mathrm{ml}$. The effect was to restore part of the reduced bactericidal activity of $\mathrm{RP}_{b}$ (Fig. 3). 


\section{Effect of serum from burned patients on the properdin-sensitive shigella}

Sera from four severely burned patients in which properdin could not be detected by the zymosan assay were found to have bactericidal action against the properdinsensitive test strain similar in degree to that obtained with normal sera (Fig. 4). None of these patients was receiving an antibiotic at the time when blood was taken.

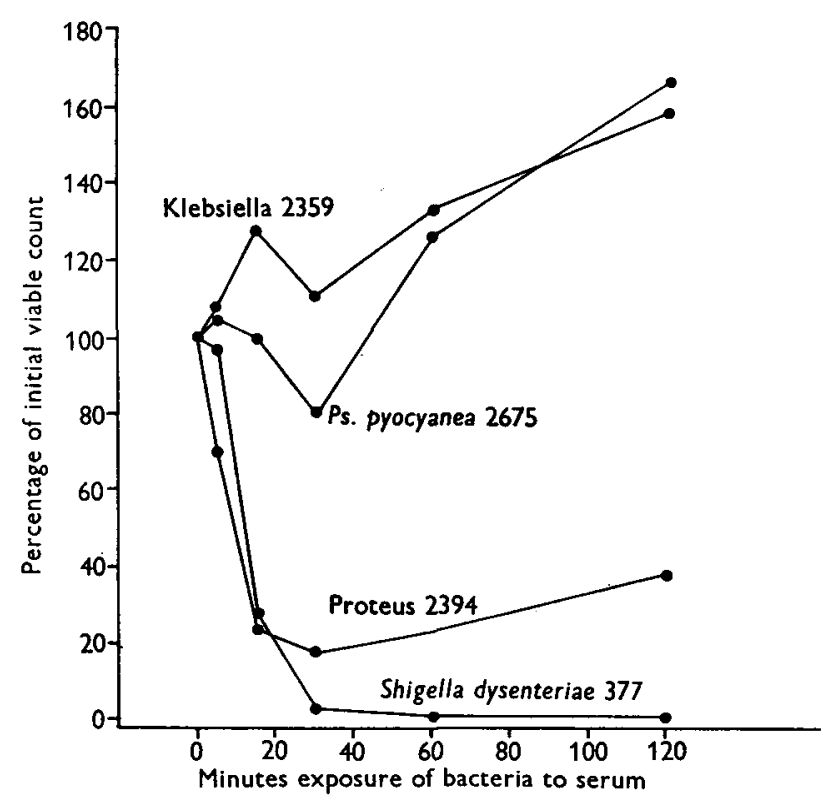

Fig. 2. Surface viable counts of three Gram-negative bacilli from burns and of a properdinsensitive control (Shigella dysenteriae 377) made at intervals after mixing suspensions of the organisms with fresh serum (approximately 10,000 organisms per ml. mixture).

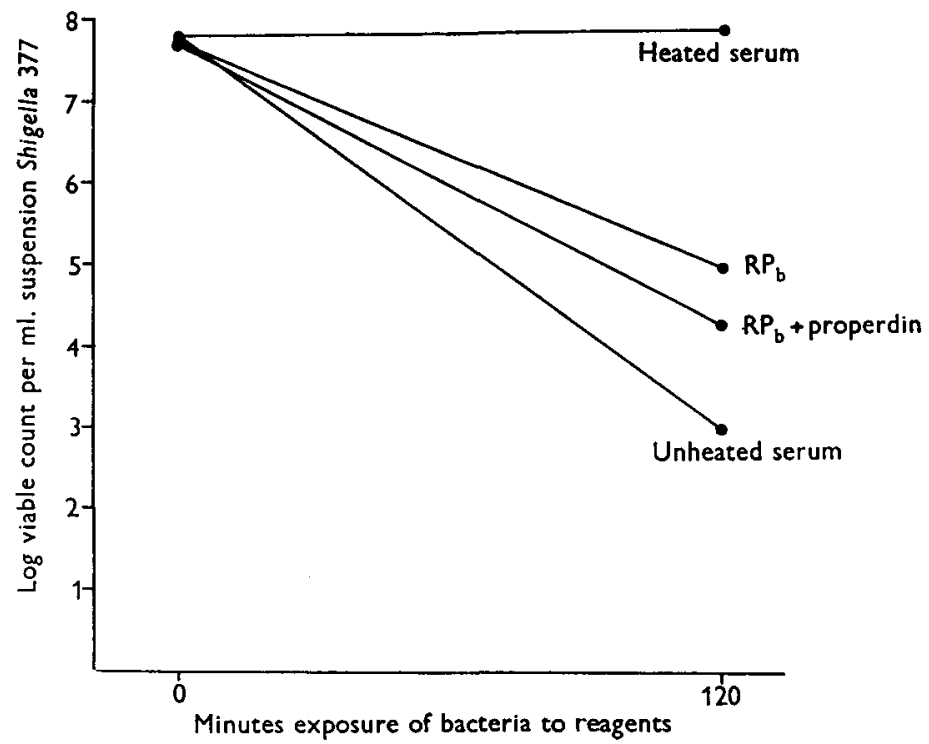

Fig. 3. Surface viable counts, by the method of Miles and Misra, of Shigella dysenteriae 377 at start and at end of $2 \mathrm{hr}$. exposure to fresh serum, $\mathbf{R P}_{b}, \mathbf{R P}_{b}+$ properdin, and heated serum. 


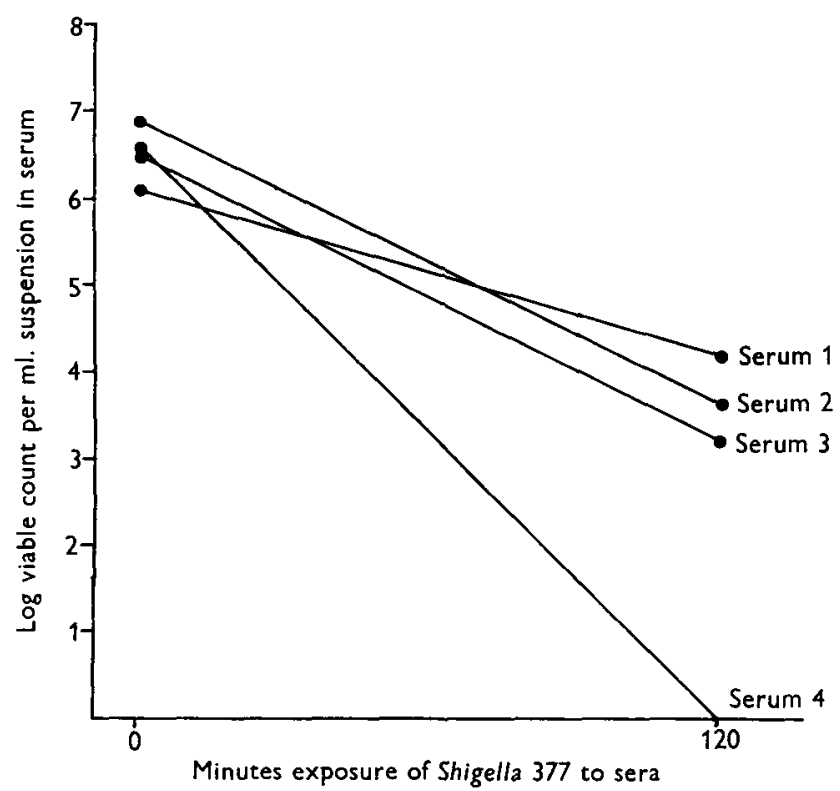

Fig. 4. Surface viable counts, by the method of Miles and Misra, of Shigella dysenteriae 377 at start and at end of $2 \mathrm{hr}$. exposure to sera from four burned patients deficient in properdin.

\section{DISCUSSION}

The insoluble polysaccharide residue from yeast cells, known as zymosan, adsorbs from serum a mixture of proteins. The presence of $\alpha_{2}, \beta$ and some $\gamma$ globulin in this mixture was demonstrated by electrophoresis on paper; it is to be expected that more sensitive methods would demonstrate many components in such a mixture. Serum which has been deprived of these proteins (RP) was shown to differ from normal serum in two respects: (1) the third component of complement could not be adsorbed on zymosan; and (2) the solution was less bactericidal. Partial restoration of these properties occurred when the mixture of proteins, designated 'properdin', was added to RP. These observations appear to us to represent only part of the truth about an exceptionally complex system, for there was considerable variation in the behaviour of individual samples of serum, zymosan and bacteria subjected to such tests.

Two reasons prompted us to look for a fall in the serum properdin level of extensively burned patients: first, the observation of Fine (1955) that the serum properdin, and also the resistance to infection, falls in dogs with haemorrhagic shock; and secondly, the presence in most extensive burns of enormous numbers of Gram-negative bacilli which contain in their cell envelopes polysaccharides such as those shown by Rowley (1955) to act on properdin in the same way as zymosan, inactivating it in vitro and also in vivo.

In our study there was a considerable range of variation in the properdin level of normal sera and of sera from burned patients, but a higher proportion of the latter showed no detectable or measurable properdin. The significance of these 
findings is hard to assess, for properdin may be undetectable by the zymosan assay method and yet present in sufficient amount to have a good bactericidal effect; this is implicit in Pillemer's account of the bactericidal test, for which a special, doubly adsorbed reagent $\left(\mathrm{RP}_{b}\right)$ is required as a source of complement on account of the bactericidal effect of the properdin still present in RP used for the zymosan assay (Pillemer, 1955). Several sera from burned patients in which no properdin could be detected by the zymosan assay showed bactericidal activity against the properdin-sensitive test strain which was comparable with that shown by normal sera containing measurable amounts of properdin. However, in view of the readiness with which properdin may be removed from the blood stream by components of bacterial cells (Rowley, 1955; Pillemer \& Ross, 1955), the zymosan assay should perhaps be regarded as defining the reserve of properdin available to meet an infective emergency rather than the immediate bactericidal capacity of the blood. Even if this interpretation is conceded, the zymosan assay is defective because of the difficulty of obtaining standard reagents, and because of the number of 'indefinite' results in which anti-sheep haemolysin in the patient's serum prevents $100 \%$ inhibition of haemolysis in any tube of the assay. A simpler and more sensitive test is needed.

As staphylococci have been found insensitive to the properdin system (Rowley, personal communication), we restricted our bactericidal tests to Gram-negative bacilli. Most of the tests were made by a method which would show large differences in sensitivity, and were therefore relevant particularly to the elimination of established infection. Three 'resistant' strains were also tested by a method more suitable for the detection of minor degrees of sensitivity, and therefore perhaps more relevant to prophylaxis of uninfected tissues. It was interesting that four out of five strains of Bact. coli, which is relatively uncommon in burns, were highly sensitive to the bactericidal action of serum, whereas all but one of the fourteen strains of Gram-negative bacilli usually found in burns (Ps. pyocyanea, Proteus and Klebsiella) were resistant or relatively resistant. It seems that in the burn there may be a process of selection of organisms resistant to properdin which is analogous to the selection of organisms resistant to antibiotics in use (e.g., Lowbury, Topley \& Hood, 1952).

In our view, therefore, properdin cannot be regarded as a promising new kind of antibiotic for the treatment of infected wounds and burns. It seems likely, however, that it plays an important part as a component of the natural defences; for example, the strain of Proteus shown in Fig. 2 to be slightly sensitive to the bactericidal action of serum might be excluded, even if it could not be eliminated, from a lesion by this mechanism (which was probably, but not certainly, the properdin system). Therapeutic uses for properdin may be found in special circumstances-e.g. in radiation sickness where there is evidence that properdin, together with other antibacterial mechanisms, is lost; in such cases the administration of properdin may be valuable (Pillemer et al. 1954) as a measure against the invasion by properdin-sensitive coliforms from the alimentary canal. 


\section{SUMMARY}

Treatment of serum with the insoluble polysaccharide residue of yeast cells (zymosan) has been shown (a) to decrease the bactericidal power of serum for certain bacteria; $(b)$ to remove from some sera a factor essential to the interaction of zymosan with the third component of complement. The adsorbed protein (properdin) was eluted from zymosan and found to contain $\alpha_{2}, \beta$ and some $\gamma$ globulins. It was shown to restore partially the normal characteristics to treated serum (RP).

Properdin levels have been estimated in the sera of eighteen burned patients and in twelve normal subjects. There was evidence of a reduced level in the patients' sera. The limitations of the assay method are discussed.

Bactericidal activity of normal serum containing properdin was tested against nineteen Gram-negative bacilli isolated from burns. Ps. pyocyanea, Proteus and Klebsiella, which are commonly found in burns, were with one exception resistant or slightly sensitive to the bactericidal action of this serum. Bact. coli, which is uncommon in burns, was usually highly sensitive.

From our preliminary studies reported here it would seem that the properdin system cannot be expected to kill the flora in established infections of burns, and properdin is therefore unlikely to prove useful as a therapeutic agent. However, it probably has an important role as one of the defence mechanisms of uninfected tissues.

We wish to thank Dr Derrick Rowley and Dr A. C. Wardlaw for helpful discussions, and Dr W. Weiner for his advice and co-operation. We are grateful to Miss Stella Baar, F.R.I.C., for $\mathrm{N}$ and $\mathrm{P}$ analyses.

\section{REFERENCES}

Fine, J. (1955). Ann. Surg. 142, 361.

Foster, A. (1953). J. chem. Soc. p. 982.

Lowbury, E. J. L., Topley, E. \& Hood, A. M. (1952). Lancet, i, 1036.

Mmes, A. A., Misra, S. S. \& Irwin, J. O. (1938). J. Hyg., Camb., 38, 732.

Pillemer, L. (1955). Trans. N.Y. Acad. Sci. (Ser. II), 17, 526.

Pillemer, L., Blum, L., Lepow, I. H., Ross, O. A.,Todd, E. W. \& Wardlaw, A. C. (1954). Science, 120, 279.

Pillemer, L., Blum, L., Lepow, I. H., Wurz, L. \& Todd, E. W. (1956). J. exp. Med. 103, 1.

Pillemer, L. \& Ecker, E. E. (1941). J. biol. Chem. 137, 139.

Piftemer, L. \& Ross, O. A. (1955). Science, $121,732$.

Pillemer, L., Schomaberg, M. D., Blum, L. \& Wurz, L. (1955). Science, 122, 545.

ROWLEY, D. (1955). Lancet, i, 232.

Trevelyan, W. E. \& Harrison, J. S. (1952). Biochem. J. 50, 298.

Wardiaw, A. C. \& Pillemer, L. (1956). J. exp. Med. 103, 553.

(MS. received for publication 31. VII. 56) 